\title{
Sites of In Vivo Extraction and Interconversion of Testosterone and Androstenedione in Dogs
}

\author{
Alcide Chapdelaine \\ From the Departments of Laboratories and Medicine, Maisonneuve Hospital \\ and the University of Montreal, Montreal, Canada
}

A B STRACT The interconversion and extraction of testosterone and androstenedione across and within different tissues or areas have been studied by the constant infusion technique. The results were calculated using the ${ }^{8} \mathrm{H} /{ }^{14} \mathrm{C}$ ratios and radioactive concentrations of testosterone and androstenedione obtained from afferent and efferent blood and tissues at equilibrium. In each tissue studied, the interconversion between testosterone and androstenedione inside the tissue was significantly higher than the corresponding interconversion across the tissue. The pulmonary contribution to the total interconversion between testosterone and androstenedione was far more important than that of any of the other tissues studied. The hepatic metabolic clearance rates of testosterone and androstenedione were not different from their metabolic clearance rates in the mesenteric area. The extraction of each of these compounds, although not negligible, was lower in the kidney and the femoral bed compared with the extraction in the liver and the mesenteric area. Finally, with the possible exception of the liver, testosterone and androstenedione were more completely metabolized when they originated from the cells than from afferent blood.

The evaluation of these different tissue transfer constants provides more precise information concerning the relative importance of different sites in the metabolism of these interconverting hormones.

\section{INTRODUCTION}

In recent years, many problems related to the secretion and metabolism of androgens, principally testosterone (T) and androstenedione $(\Delta)$ have been studied and partly elucidated (1-9). For these two steroids, blood production rates, contribution of other precursors to blood production rates, and their metabolic clearance

A portion of this work was presented at the International Congress on Hormonal Steroids, Milan, 1966.

Received for publication 15 April 1969. rates are well documented $(2,5,7,8,10)$. It has also been clearly demonstrated (5) that, in the normal female, $60 \%$ of the circulating testosterone is derived from androstenedione by peripheral conversion.

Many aspects, however, such as the anatomical sites of their interconversion and metabolism are uncertain. In a study of the role of the splanchnic organs in the metabolism of $T$ and $\Delta$, Horton and Tait (5) have indirectly calculated that the conversion of $\Delta$ to $T$ was mostly extrasplanchnic. However, their calculations depend on four assumptions which have not yet been completely verified experimentally. Thus, it is difficult to evaluate to what extent their calculations will be influenced if their assumptions are not completely applicable. Using a more direct approach, Rivarola, Singleton, and Migeon (9) have also found that the interconversion between $\mathrm{T}$ and $\Delta$ was mostly extrasplanchnic.

What also remains to be elucidated are the tissue metabolic clearance rates of $T$ and $\Delta$ and their relative contribution to the total metabolic clearance rates. In humans, Rivarola et al. (9) did not find any extraction of $T$ and $\Delta$ by the renal tissue. However, in the splanchnic system, $44 \%$ of $T$ and $83 \%$ of $\Delta$ were extracted after one passage.

On the other hand, several tissues (as studied in vitro) can interconvert and, in some cases, metabolize testosterone and androstenedione, as shown for the muscle (11), the skin $(12,13)$, the prostate (14), the kidney $(15,16)$, and the digestive tract (17)

To study these different aspects, we have designed experiments which allow us to measure the interconversion between $T$ and $\Delta$ and their extraction across different tissues or areas. The relative contribution of each of these tissues to the total interconversion between $\mathrm{T}$ and $\Delta$ and their metabolic clearance rates have also been calculated.

\section{METHODS}

Reagents. Methylene chloride, ethyl acetate, benzene, acetone, ligroin, methylcyclohexane, toluene, dichloromethane, 
cyclohexane, and hexane were all of spectral quality ${ }^{1}$ and used without further purification. Methanol was redistilled twice. Ethanol was purified over $m$-phenylenediamine dihydrochloride and redistilled four times.

Chromatography. Chromatography paper was washed with redistilled methanol in a Friedrichs condenser ${ }^{2}$ for 12 hr. Eastman chromatogram sheets, type K-301R2, coated with silica gel $^{1}$ were used for thin-layer chromatography. The plates were heated to $100^{\circ} \mathrm{C}$ for $1 \mathrm{hr}$ and stored in a desiccator before use. Chromatographic systems used in this work are described later in the text. Gas-liquid chromatography was done on a gas chromatograph, Packard model 871 , at $240^{\circ} \mathrm{C}$, on a Chromosorb-2 (80-120 mesh) column, coated with $3 \%$ SE-30.

Labeled steroids. Androstenedione-1,2- ${ }^{8} \mathrm{H}(50 \mathrm{mc} /$ mmole) and testosterone- $4-{ }^{14} \mathrm{C}(58 \mathrm{mc} / \mathrm{mmole})$ were obtained commercially from New England Nuclear Corp., Boston, Mass. These stock solutions were evaporated under nitrogen, diluted with purified ethanol, and stored at $0^{\circ} \mathrm{C}$. To test for purity of the labeled steroids, a portion of each was added to $300 \mu \mathrm{g}$ of authentic steroid ${ }^{3}$ and the mixture was carried through three successive chromatographies (systems 4,5 , and 2 , see text). The specific activity was estimated before and after each chromatography by measuring the mass of steroid by absorption at $240 \mathrm{~m} \mu$ in ethanol, or by gas chromatography, and the radioactivity was assayed by liquid scintillation spectrometry. The specific activity remained constant for each steroid.

Measurement of radioactivity. Each sample was transferred to a counting vial with absolute ethanol, dried, and counted in $10 \mathrm{ml}$ of toluene containing $0.4 \% 2,5$-diphenyloxazole and $0.005 \%$ 1,4-bis-2-(5-phenyloxazolyl) benzene, using a Packard liquid scintillation spectrometer, model 3375. All counting was corrected for quenching with an external standard; discriminator and gain settings were such to give an efficiency of $61.6 \%$ for ${ }^{14} \mathrm{C}\left({ }^{8} \mathrm{H}\right.$ then $\left.0.1 \%\right)$ and $31.2 \%$ for ${ }^{8} \mathrm{H}\left({ }^{14} \mathrm{C}\right.$ then $\left.8.2 \%\right)$ with backgrounds of 9.8 and $9.7 \mathrm{cpm}$ respectively. Samples were counted three or four times for 20 min or longer so that the SE was less than $5 \%$.

Subjects. 11 normal male and 2 normal female (dogs 1-2 and 1-5) mongrel dogs, weighing between 17 and $38 \mathrm{~kg}$ were used in this study. All experiments were started between 8 and 9 a.m. Dogs were anesthetized with pentobarbital. 2.4 $5.5 \mu \mathrm{c}$ of androstenedione-1,2,- ${ }^{8} \mathrm{H}$ and $0.31-1.0 \mu \mathrm{c}$ of testosterone-4- ${ }^{14} \mathrm{C}$ were injected into a foreleg vein in $10 \mathrm{ml}$ of $10 \%$ ethanol in saline as a priming dose. 30 min later, a mixture of the same radioactive steroids diluted in $25 \mathrm{ml}$ of $10 \%$ ethanol in saline was given as a constant infusion using a $30 \mathrm{ml}$ Yale glass syringe fitted to a Harvard infusion pump " model 600-910/920. Rates of infusion varied from 0.546 to $1.36 \mu \mathrm{c} / \mathrm{min}$ for androstenedione $-1,2-{ }^{8} \mathrm{H}$ and from 0.05 to $2.2 \mu \mathrm{c} / \mathrm{min}$ for testosterone $-4{ }^{14} \mathrm{C}$. Perfusion was performed via a Teflon ${ }^{5}$ catheter to avoid adsorption of radioactive steroid (18). In most cases, infusion lasted approximately $180 \mathrm{~min}$ or more since it was previously established, in two dogs not included in this study, that equilibrium had not been reached after $135 \mathrm{~min}$ of perfusion. With the exception of the first three dogs, the arterial-1 blood samples were taken $140 \mathrm{~min}$ or more after the begin-

${ }^{1}$ Fisher Scientific Company, Fair Lawn, N. J.

2 Canlab Co., 8655 Delmeade Road, Montreal.

${ }^{3}$ Obtained from Steraloids Inc., Pawling, N. Y.

- Harvard Apparatus Co., Inc., Dover, Mass.

- Johnston Industrial Plastics, 103 Smith, Ville Lasalle, Québec, Canada. ning of the infusion and the other blood samples 160-196 min after the beginning of the infusion. The amounts of blood taken varied between 50 and $115 \mathrm{ml}$.

Sampling of blood and tissue. At the beginning of each experiment, Teflon catheters were placed into the femoral artery and vein. During the first $30 \mathrm{~min}$ of the infusion, a laparotomy was performed and polyethylene catheters were introduced into the portal and renal veins, as described by Herd and Barger (19) in order to avoid disturbance of tissue blood flow. In each instance, the left spermatic vein was ligatured. At the end of the perfusion period, blood samples were withdrawn through these catheters (Table III). Blood from the right heart was taken by means of a catheter introduced into the right ventricle through a jugular vein. The hepatic vein sample was withdrawn through a Tefion catheter placed into the inferior vena cava up to the level of the hepatic veins. Immediately before sampling the blood, the inferior vena cava was tightly ligatured below and above the hepatic veins; the first $5 \mathrm{ml}$ of blood were discarded. All blood samples were withdrawn into $50 \mathrm{ml}$ heparinized syringes and immediately transferred into an Erlenmeyer flask containing $300 \mu \mathrm{g}$ of authentic $\mathrm{T}$ and $\Delta$ and $100 \mathrm{ml}$ of $50 \%$ methanol in order to stop any further metabolism of $\mathrm{T}$ and $\Delta$ by the blood (20). Immediately after, different tissues were taken, washed under running water, and rapidly homogenized in $35 \%$ methanol with a Virtis homogenizer. ${ }^{1}$

Purification of samples. Each blood and tissue sample was further diluted to a final concentration of $33 \%$ methanol and dialyzed four times against $40 \%$ methanol (21). The dialysates, after the evaporation of methanol, were extracted three times with equal volumes of chloroform. The aqueous phase was then adjusted to $\mathrm{pH} 4.5$ with hydrochloric acid and incubated at $37^{\circ} \mathrm{C}$ for $24 \mathrm{hr}$ with $\beta$-glucuronidase enzyme ${ }^{\circ}$ $(300 \mathrm{U} / \mathrm{ml})$; after the addition of $100 \mu \mathrm{g}$ of authentic testosterone, the mixture was extracted three times with equal volumes of chloroform. The free and conjugated steroid extracts were purified separately in the following manner:

(a) paper chromatography in system 3 (ligroin: methanol: water, $10: 9: 1$, at room temperature)

(b) paper chromatography in system 4 (methylcyclohexane: toluene : methanol : water, $4: 1: 4: 1$ )

(c) chromatography on thin-layer in system 5 (dichloromethane: benzene : methanol, $160: 160: 15$ ) or on paper in system 1 (petroleum ether: methanol: water, $10: 7: 3$ )

(d) In some instances, each compound was rechromatographed in two dimensions on thin-layer in system 2 (ethly acetate: benzene, $1: 1$ ) and in system 7 (ethyl acetate: methanol, $9: 1$ ).

(e) In some instances, testosterone was acetylated and and rechromatographed in system 6 (cyclohexane: methanol: water, 10:10:1) or in system 8 (ligroin: methanol: water, $10: 9: 1$ at $4^{\circ} \mathrm{C}$ ). After saponification (22) or as the acetate, it was then crystallized two or three times to constant $\left({ }^{8} \mathrm{H} /{ }^{14} \mathrm{C}\right)$ ratio.

(f) In a few cases, testosterone was oxidized to androstenedione (23), rechromatographed in system 2, and the material was then crystallized.

(g) Androstenedione was, in some cases, reduced to testosterone (24), rechromatographed in system 3 , and then crystallized two or three times to constant ${ }^{3} \mathrm{H} /{ }^{14} \mathrm{C}$ ratio.

\footnotetext{
- Obtained from Warner-Chilcott, Scarborough, Ontario.
} 
TABLE I

${ }^{3} H /{ }^{4} C$ Ratios and Radioactivity Concentrations of Teslosterone $(T)$ and Androstenedione $(\Delta)$ during the Purification Procedure* in Dog 1-4

\begin{tabular}{|c|c|c|c|c|c|c|c|c|c|c|}
\hline \multirow[b]{3}{*}{ Procedures } & & \multicolumn{9}{|c|}{ Blood samples } \\
\hline & & Arterial-1 & \multicolumn{2}{|c|}{ Arterial-2 } & \multicolumn{2}{|c|}{ Femoral vein } & \multicolumn{2}{|c|}{ Portal vein } & \multicolumn{2}{|c|}{ Hepatic vein } \\
\hline & $\mathrm{T}$ & $\Delta$ & $\mathrm{T}$ & $\Delta$ & $\mathrm{T}$ & $\Delta$ & $\mathbf{T}$ & $\Delta$ & $\mathrm{T}$ & $\Delta$ \\
\hline $\begin{array}{l}C^{*} \text { on system } 3 \text { followed } \\
\text { by } C \text { on system } 4\end{array}$ & 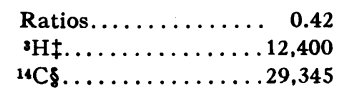 & $\begin{array}{r}13.56 \\
126,720 \\
9,340\end{array}$ & $\begin{array}{r}0.48 \\
12,510 \\
26,060\end{array}$ & $\begin{array}{r}13.60 \\
124,270 \\
9,137\end{array}$ & $\begin{array}{r}0.50 \\
11,335 \\
22,845\end{array}$ & $\begin{array}{r}13.21 \\
90,900 \\
6,880\end{array}$ & $\begin{array}{r}0.43 \\
6,490 \\
15,105\end{array}$ & $\begin{array}{r}13.17 \\
36,810 \\
2,795\end{array}$ & $\begin{array}{r}0.79 \\
7,510 \\
9,530\end{array}$ & $\begin{array}{r}7.30 \\
37,280 \\
5,105\end{array}$ \\
\hline C on system 5 & $\begin{array}{c}\operatorname{Ratios} \ldots \ldots \ldots \ldots \ldots \ldots \\
{ }^{\mathbf{2}} \mathrm{H} \ldots \ldots \ldots \ldots \ldots \ldots \ldots \\
{ }^{14} \mathrm{C} \ldots \ldots \ldots \ldots \ldots\end{array}$ & $\begin{array}{r}13.76 \\
129,015 \\
9,376\end{array}$ & & $\begin{array}{r}13.52 \\
125,150 \\
9,256\end{array}$ & & $\begin{array}{r}13.37 \\
87,915 \\
6,575\end{array}$ & & $\begin{array}{r}12.88 \\
29,825 \\
2,315\end{array}$ & & $\begin{array}{r}7.43 \\
32,130 \\
4,325\end{array}$ \\
\hline $\begin{array}{l}\text { Acetylation and C } \\
\text { on system } 8\end{array}$ & 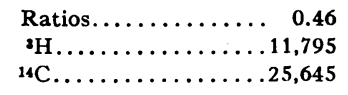 & & $\begin{array}{r}0.41 \\
12,010 \\
29,270\end{array}$ & & $\begin{array}{r}0.51 \\
10,300 \\
20,390\end{array}$ & & $\begin{array}{r}0.47 \\
5,765 \\
12,265\end{array}$ & & $\begin{array}{r}0.82 \\
7,730 \\
9,420\end{array}$ & \\
\hline $\begin{array}{l}\text { Saponification and C } \\
\text { on system } 3\end{array}$ & 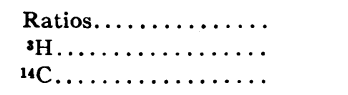 & & & & & & & & $\begin{array}{r}0.79 \\
6,705 \\
8,490\end{array}$ & \\
\hline C on system 1 & 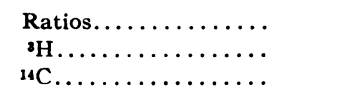 & $\begin{array}{r}13.38 \\
121,665 \\
9,095\end{array}$ & & $\begin{array}{r}13.55 \\
119,730 \\
8,836\end{array}$ & & $\begin{array}{r}13.34 \\
107,050 \\
8,025\end{array}$ & & $\begin{array}{r}13.26 \\
30,090 \\
2,270\end{array}$ & & $\begin{array}{r}7.54 \\
34,770 \\
4,610\end{array}$ \\
\hline C on system 5 & 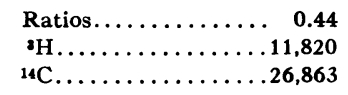 & & $\begin{array}{r}0.43 \\
12,980 \\
29,900\end{array}$ & & $\begin{array}{r}0.53 \\
10,180 \\
19,155\end{array}$ & & $\begin{array}{r}0.45 \\
5,491 \\
12,070\end{array}$ & & & \\
\hline Crystallization, 1st & Crystals. . . . . . . . 0.44 & 13.49 & 0.45 & 13.66 & 0.51 & 13.19 & 0.46 & 13.04 & 0.80 & 7.26 \\
\hline Crystallization, 2nd & $\begin{array}{l}\text { Crystals........... } \\
m l \| \ldots \ldots \ldots \ldots \ldots\end{array}$ & $\begin{array}{l}13.65 \\
13.41\end{array}$ & 0.41 & 13.46 & & 13.24 & 0.44 & 13.16 & 0.80 & $\begin{array}{l}7.50 \\
7.33\end{array}$ \\
\hline Crystallization, 3rd & $\begin{array}{l}\text { Crystals............. } \\
m l \ldots \ldots \ldots \ldots\end{array}$ & 13.59 & $\begin{array}{l}0.46 \\
0.48\end{array}$ & 13.57 & & 13.52 & $\begin{array}{l}0.44 \\
0.45\end{array}$ & 13.10 & & $\begin{array}{l}7.46 \\
7.40\end{array}$ \\
\hline Mean & 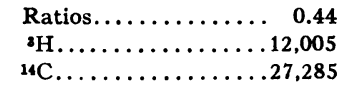 & $\begin{array}{r}13.55 \\
125,800 \\
9,270\end{array}$ & $\begin{array}{r}0.44 \\
12,500 \\
28,410\end{array}$ & $\begin{array}{r}13.56 \\
123,050 \\
9,076\end{array}$ & $\begin{array}{r}0.51 \\
10,605 \\
20,795\end{array}$ & $\begin{array}{r}13.31 \\
95,290 \\
7,160\end{array}$ & $\begin{array}{r}0.45 \\
5,915 \\
13,145\end{array}$ & $\begin{array}{r}13.10 \\
32,240 \\
2,460\end{array}$ & $\begin{array}{r}0.80 \\
7,315 \\
9,145\end{array}$ & $\begin{array}{r}7.43 \\
34,725 \\
4,680\end{array}$ \\
\hline
\end{tabular}

* Chromatography.

$\ddagger^{2} \mathrm{H}$ concentration in DPM $/ 100 \mathrm{ml}$ of whole blood corrected for losses.

$\$ 14 \mathrm{C}$ concentration in DPM/100 ml of whole blood corrected for losses.

\|I Mother liquor.

After each purification step, the recovery of added carrier was measured by absorption at $240 \mathrm{~m} \mu$ in ethanol and by gas chromatography as previously described, and radioactivity was estimated by liquid scintillation spectrometry. Over-all recoveries of authentic $T$ and $\Delta$ added to whole blood varied between $30 \%$ and $50 \%$. All radioactive concentrations are expressed in dpm per $100 \mathrm{ml}$ of whole blood and are corrected for procedural losses.

A typical example (results from dog 1-4, Table I) shows that the radioactive concentrations and the ${ }^{3} \mathrm{H} /{ }^{14} \mathrm{C}$ ratios of $\mathrm{T}$ and $\Delta$ isolated from different blood samples are quite constant throughout the purification procedures. Comparison of $T$ and $\Delta$ ratios and concentrations between the two arterial blood samples taken at 15 - to 20 -min intervals gave evidence that equilibrium in blood was obtained during the continuous infusion. If the first arterial ${ }^{8} \mathrm{H} /{ }^{14} \mathrm{C}$ ratios are compared, the mean arterial-2 ratios were $100 \%$ for $T$ and $\Delta$; if we compare radioactive concentrations, the mean arterial -2 values were $100 \pm 2.0 \mathrm{SE}$ for testosterone- ${ }^{8} \mathrm{H}, 100 \pm 2.0 \mathrm{SE}$ for testosterone- ${ }^{14} \mathrm{C}, 100 \pm 1.1 \mathrm{SE}$ for androstenedione- ${ }^{8} \mathrm{H}$, and $100 . \pm 1.0 \mathrm{sE}$ for androstenedione $-{ }^{11} \mathrm{C}$. It is evident that there is no trend in the values. All data used in the calculations are shown in Tables II and III.
Calculations and definition of terms. Metabolic clearance rates were calculated as described by Tait (25), blood transfer constants as described by Gurpide, Mann, and Lieberman (26) (see Appendix), and transfer constants through each organ were determined according to formulas (see Appendix) derived by Gurpide ${ }^{7}$, using the model shown in Fig. 1. This model represents the kidney $(K)$ with its afferent arterial (A) blood and its efferent venous (V) blood. The same model can be applied to any other organ.

Definition of terms used subsequently are as follows: $\mathrm{R}_{\mathrm{T}^{14} \mathrm{C}}$ and $R_{\Delta}{ }^{3 \mathrm{H}}$, perfusion rate of $\mathrm{T}-{ }^{14} \mathrm{C}$ and $\Delta-^{8} \mathrm{H}$ in $\mathrm{dpm}$ per day. Radioactive concentrations (c) in dpm per $100 \mathrm{ml}$ of blood are symbolized as follows: $\mathrm{c}_{\mathrm{T}_{\mathrm{A}}}{ }^{3 \mathrm{H}}$ and $\mathrm{c}_{\mathrm{T}_{\mathrm{A}}}{ }^{14 \mathrm{C}}$, concentration of testosterone- ${ }^{3} \mathrm{H}$ and ${ }^{14} \mathrm{C}$, isolated from arterial blood. ${ }^{3} \mathrm{H} /{ }^{14} \mathrm{C}$ ratios are symbolized similarly: example, $\left({ }^{3} \mathrm{H} /{ }^{14} \mathrm{C}\right) \mathrm{T}_{\mathrm{K}}$ is the ${ }^{3} \mathrm{H} /{ }^{14} \mathrm{C}$ ratio in testosterone isolated from the kidney. MCR and MCR $\Delta$, blood metabolic clearance rate of $\mathrm{T}$ and $\Delta . \rho_{\mathrm{BB}}^{\mathrm{T} \Delta}$ and $\rho \frac{\Delta \mathrm{T}}{\mathrm{BB}}$, blood transfer constants $(\rho)$ between $\mathrm{T}$ and $\Delta$.

${ }^{7}$ Gurpide, E. 1962. Personal communication. 
Transfer constants ( $\rho$ ) across or inside each tissue or area, using the kidney as an example are symbolized as follows: ${ }^{\mathrm{T} \Delta} \mathrm{AV}$, transfer constant from arterial $\mathrm{T}$ to renal venous $\Delta$ (transtissue interconversion). ${ }^{\mathrm{I} \Delta}{ }_{\mathrm{KK}}$, transfer constant from $\mathrm{T}$ to $\Delta$ inside the renal cells (intratissue interconversion). $\rho_{\mathrm{AV}}^{\mathrm{TT}}$, transfer constant from arterial $T$ to renal venous $T$. The percentage of extraction of $\mathrm{T}$ across the kidney will then be $\left[1-{ }_{\mathrm{TTV}}^{\mathrm{TT}}\right] \times 100 . \rho_{\mathrm{KV}}^{\mathrm{TT}}$, transfer constant from renal $\mathrm{T}$ to corresponding venous $T$. The percentage of extraction of $T$ formed in the kidney will then be $\left[1-\rho_{\mathrm{KV}}^{\mathrm{TT}}\right] \times 100$

The androstenedione transfer constants are expressed in the same way.

TABLE II

Data for the Determination of Blood $M C R^{T} M C R^{\Delta}(\rho), B B$, and all Transtissular $(\rho)$ *

\begin{tabular}{|c|c|c|c|c|c|c|c|c|c|c|c|c|}
\hline \multirow{3}{*}{$\begin{array}{l}\text { Dog } \\
\text { No. }\end{array}$} & & \multicolumn{11}{|c|}{ Blood samples } \\
\hline & & Arterial & \multicolumn{2}{|c|}{ Femoral vein } & \multicolumn{2}{|c|}{ Renal vein } & \multicolumn{2}{|c|}{ Portal vein } & \multicolumn{2}{|c|}{ Hepatic vein } & \multicolumn{2}{|c|}{ Right heart } \\
\hline & $\mathbf{T}$ & $\Delta$ & $\mathrm{T}$ & $\Delta$ & $\mathbf{T}$ & $\Delta$ & $\mathrm{T}$ & $\Delta$ & $T$ & $\Delta$ & $\mathrm{T}$ & $\Delta$ \\
\hline \multirow{3}{*}{1} & Ratiosł........ 1.78 & 23.08 & & & & & 1.81 & 21.19 & & & & \\
\hline & ${ }^{3} \mathrm{H} \& \ldots \ldots \ldots \ldots 16,816$ & 102,040 & & & & & 6,944 & 37,591 & & & & \\
\hline & ${ }^{14} \mathrm{C} \| \ldots \ldots \ldots \ldots 9,290$ & 4,526 & & & & & 4,233 & 1.756 & & & & \\
\hline \multirow{3}{*}{3} & Ratios....... 2.42 & 26.1 & & & & 21.3 & 2.80 & 17.51 & 3.43 & & & \\
\hline & ${ }^{2} \mathrm{H} \ldots \ldots \ldots \ldots 54,823$ & 220,807 & & & & 170,403 & 41,696 & 119,544 & 9,784 & & & \\
\hline & ${ }^{14} \mathrm{C} \ldots \ldots \ldots \ldots 22,743$ & 8,377 & & & & 7,640 & 14,524 & 6,844 & 2,871 & & & \\
\hline \multirow{3}{*}{4} & Ratios....... 1.44 & 37.23 & & & 1.59 & 22.61 & 1.48 & 34.23 & 1.98 & 20.20 & & \\
\hline & 'H $\ldots \ldots \ldots \ldots 28,787$ & 184,747 & & & 27,272 & 144,999 & 19,908 & 114,160 & 1,505 & 8,225 & & \\
\hline & ${ }^{14} \mathrm{C} \ldots \ldots \ldots \ldots 19,948$ & 4,928 & & & 17,076 & 6,403 & 13,466 & 3,330 & 756 & 419 & & \\
\hline \multirow{3}{*}{5} & Ratios... . . . . 2.25 & 30.43 & 2.76 & 28.95 & 2.79 & 27.5 & 2.88 & 26.2 & 3.05 & 27.1 & & \\
\hline & 'H $\ldots \ldots \ldots \ldots 27,525$ & 224,600 & 23,242 & 93,105 & 32,474 & 11,121 & 14,150 & 92,727 & 7,120 & 60,112 & & \\
\hline & ${ }^{14} \mathrm{C} \ldots \ldots \ldots \ldots 12,065$ & 7,403 & 8,200 & 3,216 & 11,680 & 4,025 & 4,810 & 3,410 & 2,370 & 2,229 & & \\
\hline \multirow{3}{*}{6} & Ratios....... 0.64 & 9.1 & 0.71 & 6.96 & 1.1 & 6.8 & 0.81 & 7.9 & 1.0 & 8.4 & & \\
\hline & ${ }^{\bullet} \mathrm{H} \ldots \ldots \ldots \ldots 46,265$ & 304,660 & 40,085 & 125,060 & 71,445 & 217,200 & 36,655 & 110,265 & 8,450 & 26,660 & & \\
\hline & ${ }^{14} \mathrm{C} \ldots \ldots \ldots \ldots 72,370$ & 33,479 & 56,455 & 17,970 & 62,070 & 31,560 & 47,155 & 13,760 & 7,460 & 3,175 & & \\
\hline \multirow{3}{*}{7} & Ratios....... 0.67 & 10.53 & 0.95 & 9.9 & 0.68 & 8.0 & 0.67 & 8.6 & 1.06 & 7.3 & & \\
\hline & 'H. . . . . & 273,160 & 48,425 & 173,055 & 31,422 & 256,900 & 32,257 & 244,380 & 11,530 & 72,990 & & \\
\hline & ${ }^{14} \mathrm{C} \ldots \ldots \ldots \ldots 64,840$ & 25,940 & 50,987 & 16,270 & 46,210 & 30,125 & 48,145 & 28,420 & 10,035 & 9,588 & & \\
\hline \multirow{3}{*}{9} & Ratios....... 0.66 & 11.80 & 0.87 & 9.35 & 0.79 & 8.90 & 0.85 & 10.12 & 1.29 & 7.50 & & \\
\hline & ${ }^{8} \mathrm{H} \ldots \ldots \ldots \ldots 33,627$ & 190,464 & 23,826 & 76,472 & 31,853 & 149,624 & 17,625 & 91,075 & 18,177 & 53,800 & & \\
\hline & ${ }^{14} \mathrm{C} \ldots \ldots \ldots \ldots \ldots 50,837$ & 16,140 & 27,615 & 8,180 & 39,350 & 16,854 & 21,144 & 9,000 & 14,102 & 7,254 & & \\
\hline \multirow{3}{*}{$1-0$} & Ratios........ 0.62 & 15.47 & 1.16 & 12.62 & 1.24 & 9.77 & 1.01 & 11.35 & & & & \\
\hline & ${ }^{2} \mathrm{H} \ldots \ldots \ldots \ldots 21,930$ & 145,750 & 36,855 & 129,605 & 33,600 & 92,225 & 26,660 & 83,455 & & & & \\
\hline & ${ }^{14} \mathrm{C} \ldots \ldots \ldots \ldots 35,375$ & 9,420 & 31,770 & 10,270 & 27,100 & 9,440 & 26,395 & 7,350 & & & & \\
\hline \multirow{3}{*}{$1-1$} & Ratios........ 0.215 & 11.05 & 0.27 & 9.65 & & & 0.82 & 7.95 & 0.95 & 7.01 & & \\
\hline & ${ }^{\mathbf{3}} \mathrm{H} \ldots \ldots \ldots \ldots 9,147$ & 193,252 & 9,955 & 130,195 & & & 23,820 & 94,910 & 6,945 & 18,865 & & \\
\hline & ${ }^{14} \mathrm{C} \ldots \ldots \ldots \ldots 42,547$ & 17,490 & 36,865 & 13,490 & & & 29,050 & 11,940 & 7,305 & 2,690 & & \\
\hline \multirow[t]{3}{*}{$1-2$} & Ratios.... . . . 0.58 & 8.77 & & & & & & & & & 0.25 & 24.47 \\
\hline & ${ }^{8} \mathrm{H} \ldots \ldots \ldots \ldots 36,560$ & 145,320 & & & & & & & & & 13,850 & 222,450 \\
\hline & ${ }^{14} \mathrm{C} \ldots \ldots \ldots \ldots 63,040$ & 16,570 & & & & & & & & & 55,395 & 9,090 \\
\hline \multirow{3}{*}{$1-3$} & Ratios........ 0.40 & 17.68 & 0.61 & 15.66 & & & & & & & 0.28 & 26.56 \\
\hline & ${ }^{\mathrm{s}} \mathrm{H} \ldots \ldots \ldots \ldots 16,542$ & 259,755 & 24,035 & 217,805 & & & & & & & 11,070 & 270,300 \\
\hline & ${ }^{14} \mathrm{C} \ldots \ldots \ldots \ldots{ }^{41,355}$ & 14,690 & 39,400 & 13,910 & & & & & & & 39,535 & 10,175 \\
\hline \multirow{3}{*}{$1-4$} & Ratios........ 0.44 & 13.58 & 0.51 & 13.31 & & & 0.45 & 13.10 & 0.80 & 7.42 & & \\
\hline & ${ }^{8} \mathrm{H} \ldots \ldots \ldots \ldots 12,252$ & 124,425 & 10,605 & 95,290 & & & 5,915 & 32,240 & 7,315 & 34,725 & & \\
\hline & ${ }^{1+C} \ldots \ldots \ldots \ldots 27,847$ & 9,173 & 20,795 & 7,160 & & & 13,145 & 2,460 & 9,145 & 4,680 & & \\
\hline \multirow{3}{*}{$1-5$} & Ratios.... . . 0.642 & 8.18 & & & & & & & & & 0.399 & 13.08 \\
\hline & ${ }^{2} \mathrm{H} \ldots \ldots \ldots \ldots 29,685$ & 150,445 & & & & & & & & & 25,744 & 177,993 \\
\hline & ${ }^{14} \mathrm{C} \ldots \ldots \ldots \ldots{ }_{46,238}$ & 18,391 & & & & & & & & & 64,522 & 13,608 \\
\hline
\end{tabular}

* MCRT MCRA ( $\rho$ ) BB and all transtissular ( $\rho$ ) are defined in the text. $\mp$ 'H/MC ratios.

' $\mathrm{H}$ concentration in DPM/100 ml of whole blood corrected for losses. | $14 \mathrm{C}$ concentration in DPM/100 $\mathrm{nl}$ of whole blood corrected for losses. 
TABLE III

Data for the Determination of all Intratissular $(\rho)^{*}$

\begin{tabular}{|c|c|c|c|c|c|c|c|c|c|c|c|}
\hline \multirow[b]{3}{*}{ No. } & & \multicolumn{10}{|c|}{ Tissue samples } \\
\hline & & \multicolumn{2}{|c|}{ Liver } & \multicolumn{2}{|c|}{ Mesenteric area } & \multicolumn{2}{|c|}{ Kidney } & \multicolumn{2}{|c|}{ Muscle } & \multicolumn{2}{|c|}{ Lung } \\
\hline & & $\mathrm{T}$ & $\Delta$ & $\mathrm{T}$ & $\Delta$ & $\mathrm{T}$ & $\Delta$ & $\mathbf{T}$ & $\Delta$ & $\mathrm{T}$ & $\Delta$ \\
\hline 4 & Ratios $\ddagger$ & 5.51 & 11.81 & & & & & & & & \\
\hline 6 & Ratios & & & 1.4 & 6.3 & & & 0.9 & 7.8 & & \\
\hline 7 & Ratios & 1.46 & 6.5 & & 7.86 & 2.15 & 5.1 & 1.1 & 9.7 & 3.0 & 4.5 \\
\hline 9 & Ratios & 1.51 & 7.65 & 1.02 & 8.80 & 2.10 & 5.31 & & & 2.96 & 3.78 \\
\hline $1-0$ & Ratios & & & & & 1.87 & 4.85 & 0.72 & 11.22 & & \\
\hline $1-1$ & Ratios & & & & & & & 0.65 & 9.82 & & \\
\hline $1-2$ & Ratios & & & & & & & & & 2.37 & 5.38 \\
\hline $1-3$ & Ratios & & & & & & & & 12.73 & 2.50 & \\
\hline $1-4$ & Ratios & & 6.11 & 0.53 & 7.99 & & & 0.47 & 10.51 & & \\
\hline $1-5$ & Ratios & & & & & & & & & & 4.38 \\
\hline
\end{tabular}

* All intratissular ( $\rho)$ are defined in the text.

$\ddagger^{\circ} \mathrm{H} /{ }^{14} \mathrm{C}$ ratios.

\section{RESULTS}

Metabolic clearance rate (Table IV). The metabolic clearance rate of testosterone $\left(\mathrm{MCR}^{\mathrm{T}}\right)$ was $1502 \pm 113$ (SE) liters/day (13 subjects). There was no significant difference between male and female dogs. The metabolic clearance rate of androstenedione $\left(\mathrm{MCR}^{\Delta}\right)$ was also identical in male and female dogs; mean value of 1741 \pm 140 (SE) liters/day (13 subjects). Furthermore, there appears to be no significant difference between the metabolic clearance rates of $\mathrm{T}$ and $\Delta$ in $\operatorname{dogs}(P>0.05, t$ test).

Blood transfer constants (Table IV). The blood transfer constants $\left(\rho_{\mathrm{BB}}^{\mathrm{T} \Delta}\right.$ and $\left.\rho_{\mathrm{BB}}^{\Delta \mathrm{T}}\right)$ are calculated from the ${ }^{3} \mathrm{H} /{ }^{14} \mathrm{C}$ ratios of the infused mixture and of the androstenedione and testosterone isolated from the arterial blood (26). The transfer constant from blood $\mathrm{T}$ to blood $\Delta$ was $41.6 \pm 2.9 \% \mathrm{SE}$ in males (11 subjects), and $45 \%$ in females (2 subjects); these values are not statistically different. The transfer constant from blood $\Delta$ to blood T was $13.6 \pm 1.2 \%$ sE in 11 male dogs and $10.5 \pm 6.5 \mathrm{SE}$ in 2 female dogs; these values are also not statistically different. The combined values were respectively $42 \pm 2.5 \%$ SE and $13 \pm 1.3 \% \mathrm{SE}$; the $\rho_{\mathrm{BB}}^{\mathrm{T} \Delta}$ is significantly higher than the $\rho_{\mathrm{BB}}^{\Delta \mathrm{T}}(P<0.01)$.

Tissue transfer constants (Table $V$ ). ${ }^{8} \mathrm{H} /{ }^{44} \mathrm{C}$ ratios and radioactive concentrations of $\mathrm{T}$ and $\Delta$, used in the equations as hepatic arterial values, were calculated assuming that, in the anesthetized $\operatorname{dog}, 80 \%$ of the blood entering the liver comes from the portal vein and $20 \%$ from the hepatic arteries (27). The mesenteric area includes all tissues between the artery and the portal vein, in other words, the digestive tract, its mesentery and the intestinal adipose tissue. Similarly, the posterior limb includes all tissues between the femoral artery and vein, principally the bone, muscle, skin, and subcutaneous tissue.

The interconversion between $T$ and $\Delta$, across and inside the liver, mesenteric area, posterior limb, and kidney, does not significantly favor the formation of an-

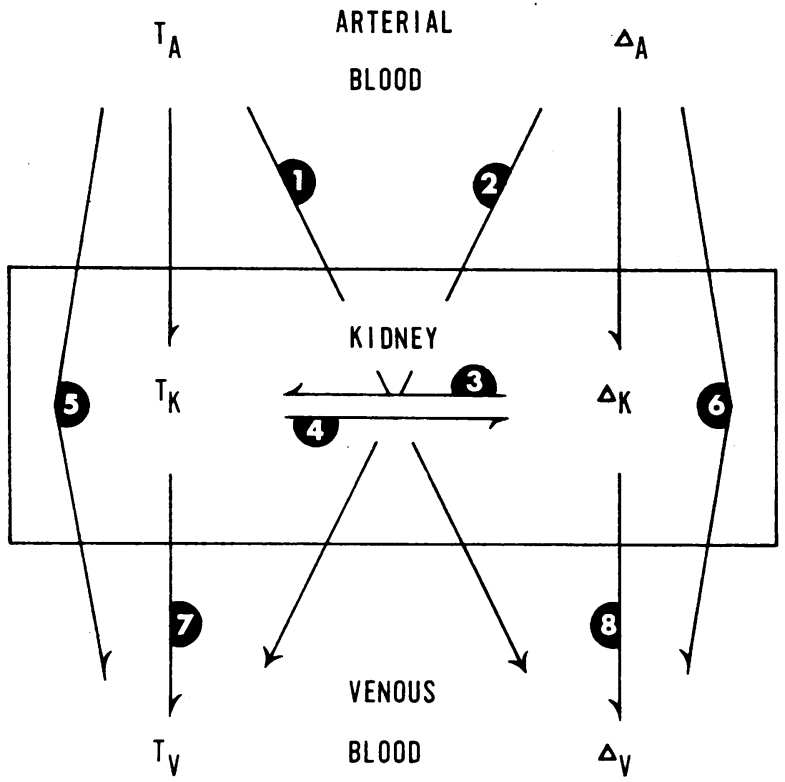

FIGURE 1 Model describing the renal (K) transfer constants ( $\rho)$. Each arrow, from 1 to 8 , represents a specific transfer

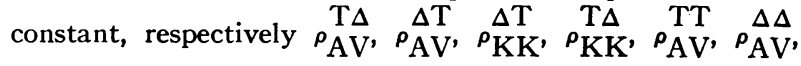
${ }_{\rho_{\mathrm{KV}}^{\mathrm{TT}}}^{\mathrm{T}}$, and $\rho_{\mathrm{KV}}^{\Delta \Delta}$ 
drostenedione (in each case, $P>0.1$ for the interconversion across and $P>0.3$ for the interconversion inside). Across and inside the lung, the interconversion seems to favor the formation of androstenedione, but the $P$ values could not be calculated from so few data. In each tissue studied, the interconversion between $T$ and $\Delta$ inside the tissue was significantly higher than the corresponding interconversion across the tissue (in all cases, $P<0.05$ ).

Across the liver, mesenteric area, kidney, and posterior limb, the extraction of $\mathrm{T}$ was not significantly different from the extraction of $\Delta$ (in each case, $P>$ 0.1 ). The extraction of $T$ and $\Delta$ was similar across the kidney and the posterior limb, but significantly higher across the liver and the mesenteric area. Except for the posterior limb, the extraction of $T$ and $\Delta$ preformed in each tissue was significantly higher than the corresponding transtissue extraction (in all cases, $P<0.01$ ). The transpulmonary extraction of $\mathrm{T}$ and $\Delta$ was highly variable (see Discussion) and these values were not used in the calculations of the tissue metabolic clearance rates.

Tissue metabolic clearance rates (Table VI). The tissue metabolic clearance rate (liters/day) is defined as the product of tissue blood flow multiplied by the corresponding transtissue extraction, divided by 100 . It should be pointed out that the metabolic clearance

TABLE IV

Metabolic Clearance Rates and Total in Vivo Interconversion of Testosterone and Androstenedione

\begin{tabular}{|c|c|c|c|c|}
\hline Dog & $\mathrm{MCR}^{\mathrm{T}}$ & $\mathrm{MCR}^{\Delta}$ & $\rho_{\mathrm{BB}}^{\mathrm{T} \Delta^{*}}$ & $\rho_{\mathrm{BB}}^{P \mathrm{~T}^{*}}$ \\
\hline & liters/day+ & liters/day $\ddagger$ & & \\
\hline 1 & 1719 & 1440 & 46 & 17 \\
\hline 2 & 1208 & 1334 & 41 & 23 \\
\hline 4 & 1329 & 1859 & 29 & 13 \\
\hline 5 & 1774 & 1281 & 43 & 17 \\
\hline 6 & 970 & 1163 & 55 & 13 \\
\hline 7 & 1084 & 1298 & 48 & 13 \\
\hline 9 & 1382 & 1861 & 42 & 13 \\
\hline $1-0$ & 1896 & 2390 & 32 & 12 \\
\hline $1-1$ & 1576 & 1802 & 45 & 4 \\
\hline $1-2$ & 1064 & 2397 & 57 & 12 \\
\hline $1-3$ & 1622 & 1340 & 28 & 8 \\
\hline $1-4$ & 2459 & 2769 & 37 & 9 \\
\hline $1-5$ & 1451 & 1699 & 45 & 17 \\
\hline Mean & 1502 & 1741 & 42 & 13 \\
\hline $\mathrm{SE}$ & \pm 113 & \pm 140 & \pm 2.5 & \pm 1.3 \\
\hline
\end{tabular}

${ }^{*} \rho_{\mathrm{BB}}^{\mathrm{T} \Delta}$ and $\rho_{\mathrm{BB}}^{\Delta \mathrm{T}}$ were calculated from the perfused ${ }^{3} \mathrm{H} /{ }^{14} \mathrm{C}$ ratios and the ${ }^{3} \mathrm{H} /{ }^{14} \mathrm{C}$ ratios in testosterone and androstenedione isolated from arterial blood. $\ddagger \mathrm{MCR}^{\mathrm{T}}$ and $\mathrm{MCR}^{\Delta}$ are expressed in liters/day of whole blood. rate of each tissue is also expressed in liters/day of whole blood to avoid possible error due to different partition coefficients between plasma and red cells (28). If we assume the cardiac output to be $125 \mathrm{ml} / \mathrm{min}$ per $\mathrm{kg}$ in the anesthetized dog (29), each tissue blood flow can be estimated as a percentage of the total cardiac output. The values used in our calculations were as follows: liver blood flow, $25 \%$ of the cardiac output $(30,31)$; mesenteric area blood flow or portal blood flow, $20 \%(29,32,33)$; renal blood flow, $20 \%$ (34); and blood flow in the femoral bed, approximately $12 \%$. It is also important to realize that these different blood flows can vary widely.

The hepatic metabolic clearance rates were corrected for the fact that $80 \%$ of the liver blood flow, corresponding to the portal blood flow, has already crossed the mesenteric area which extracts $42 \%$ and $51 \%$ of the arterial testosterone and androstenedione. The hepatic $M C R^{\mathbf{T}}$ is higher than the hepatic $\mathrm{MCR}^{\Delta}$ $(P<0.01)$. In the kidneys and mesenteric area, $\mathrm{MCR}^{\mathrm{T}}$ is not significantly different from $\mathrm{MCR}^{\Delta}(P>0.3$ in both tissues). In the femoral bed, $\mathrm{MCR}^{\Delta}$ is higher than $\mathrm{MCR}^{\mathrm{T}}(P<0.02)$.

The hepatic $\mathrm{MCR}^{\mathrm{T}}$ is not significantly different from the mesenteric $\mathrm{MCR}^{\mathrm{T}}(P>0.2)$. However, the testosterone metabolic clearance rates in the liver and in the mesenteric area are significantly higher than $\mathrm{MCR}^{\mathbf{T}}$ in the renal and femoral bed $(P<0.01$ in each case $)$. The hepatic $M^{2} R^{T}$ is not significantly different from the sum of the $\mathrm{MCR}^{\mathrm{T}}$ in the mesenteric area, kidneys, and posterior limbs $(P>0.3)$.

The hepatic and mesenteric $\mathrm{MCR}^{\Delta}$ are not different $(P>0.8)$, but are definitely higher than the renal and femoral $\mathrm{MCR}^{\Delta}(P<0.05$ in each instance). Also the renal $\mathrm{MCR}^{\Delta}$ is not different from the femoral $\mathrm{MCR}^{\Delta}$ $(P>0.8)$. The sum of the $\mathrm{MCR}^{\Delta}$ in the mesenteric area, kidneys, and posterior limbs appears higher than the hepatic $\mathrm{MCR}^{\Delta}$ but the difference is not significant $(P>0.1)$.

Contribution of each tissue to the total conversion between $T$ and $\Delta$ (Table VI). To evaluate the relative contribution of each tissue to the total interconversion between $T$ and $\Delta$, each transtissue transfer constant was compared with the total blood transfer constant between $T$ and $\Delta$, using the formula shown in the second footnote $(\ddagger)$ of Table VI. The pulmonary contribution to the total interconversion between $T$ and $\Delta$ is far more important than any of the other tissues studied, while the renal contribution to the total interconversion between $\mathrm{T}$ and $\Delta$ was slightly higher than the contribution of the mesenteric area and posterior limbs $(P<0.05)$, but is not different from the hepatic contribution $(P>$ 0.1 ).

\section{A. Chapdelaine}


TABLE V

Tissue Transfer Constants $(\rho) *$ and Extractions $\ddagger$

\begin{tabular}{|c|c|c|c|c|c|c|c|c|c|}
\hline \multirow{3}{*}{$\begin{array}{l}\text { Tissue or } \\
\text { area }\end{array}$} & & \multirow{2}{*}{\multicolumn{2}{|c|}{ Transtissue $(\boldsymbol{p})$}} & \multirow{2}{*}{\multicolumn{2}{|c|}{ Intratissue $(\rho)$}} & \multicolumn{2}{|c|}{ Transtissue extraction $\ddagger$} & \multicolumn{2}{|c|}{ Intratissue extraction+ } \\
\hline & & & & & & $\mathrm{T}$ & $\Delta$ & $\mathrm{T}$ & $\Delta$ \\
\hline & & $\rho \mathrm{T} \Delta$ & $\rho \Delta \mathrm{T}$ & $\rho \mathrm{T} \Delta$ & $\rho \Delta \mathrm{T}$ & $(1-\mathrm{AV}$ & $(1-\mathrm{AV})$ & & $(1-\mathrm{KV})$ \\
\hline Liver & $\begin{array}{l}\text { Mean } \pm \text { SE } \S \\
\text { SD! } \\
\text { No. of dogs }\end{array}$ & $\begin{array}{c}4.3 \pm 1.8 \\
4.8 \\
(7)\end{array}$ & $\begin{array}{c}2.7 \pm 0.9 \\
2.6 \\
(8)\end{array}$ & $\begin{array}{c}31.5 \pm 8.6 \\
17.2 \\
(4)\end{array}$ & $\begin{array}{c}31.7 \pm 11.7 \\
20.2 \\
(3)\end{array}$ & $\begin{array}{c}72.6 \pm 6.4 \\
18.0 \\
(8)\end{array}$ & $\begin{array}{c}66.8 \pm 8.2 \\
21.7 \\
(7)\end{array}$ & $\begin{array}{c}85.0 \pm 9.9 \\
17.2 \\
(3)\end{array}$ & $\begin{array}{c}72.0 \pm 11.5 \\
22.9 \\
(4)\end{array}$ \\
\hline Mesenteric area & $\begin{array}{l}\text { Mean } \pm S E \\
\text { SE } \\
\text { No. of dogs }\end{array}$ & $\begin{array}{c}4.6 \pm 1.1 \\
3.5 \\
(10)\end{array}$ & $\begin{array}{c}2.6 \pm 1.0 \\
3.2 \\
(10)\end{array}$ & $\begin{array}{c}19.0 \pm 2.9 \\
5.9 \\
(4)\end{array}$ & $\begin{array}{c}11.0 \pm 5.5 \\
9.5 \\
(3)\end{array}$ & $\begin{array}{c}42.0 \pm 4.1 \\
13.1 \\
(10)\end{array}$ & $\begin{array}{c}51.0 \pm 5.4 \\
17.2 \\
(10)\end{array}$ & $\begin{array}{c}87.0 \pm 4.9 \\
8.5 \\
(3)\end{array}$ & $\begin{array}{c}77.0 \pm 12.3 \\
24.7 \\
(4)\end{array}$ \\
\hline Kidney & $\begin{array}{l}\text { Mean } \pm \text { SE } \\
\text { SD } \\
\text { No. of dogs }\end{array}$ & $\begin{array}{c}9.4 \pm 1.2 \\
3.4 \\
(7)\end{array}$ & $\begin{array}{c}4.9 \pm 2.0 \\
4.9 \\
(6)\end{array}$ & $\begin{array}{c}54.0 \pm 6.6 \\
11.3 \\
(3)\end{array}$ & $\begin{array}{c}42.0 \pm 3.6 \\
6.2 \\
(3)\end{array}$ & $\begin{array}{c}20.0 \pm 3.6 \\
8.8 \\
(6)\end{array}$ & $\begin{array}{c}28.0 \pm 5.1 \\
13.6 \\
(7)\end{array}$ & $\begin{array}{c}86.0 \pm 10.6 \\
18.3 \\
(3)\end{array}$ & $\begin{array}{c}81.0 \pm 2.6 \\
4.5 \\
(3)\end{array}$ \\
\hline Posterior limb & $\begin{array}{l}\text { Mean } \pm S E \\
\text { SD } \\
\text { No. of dogs }\end{array}$ & $\begin{array}{c}3.3 \pm 0.7 \\
2.1 \\
(8)\end{array}$ & $\begin{array}{c}3.7 \pm 1.3 \\
3.7 \\
(8)\end{array}$ & $\begin{array}{c}8.5 \pm 1.59 \\
3.7 \\
(6)\end{array}$ & $\begin{array}{c}9.4 \pm 2.8 \pi \\
6.3 \\
(5)\end{array}$ & $\begin{array}{c}23.0 \pm 4.5 \\
12.8 \\
(8)\end{array}$ & $\begin{array}{c}37.6 \pm 7.0 \\
19.9 \\
(8)\end{array}$ & & \\
\hline Lung & $\begin{array}{l}\text { Mean } \pm \text { SE } \\
\text { SD } \\
\text { No. of dogs }\end{array}$ & $\begin{array}{c}14.3 \pm 2.6 \\
4.5 \\
(3)\end{array}$ & $\begin{array}{c}5.9 \pm 2.2 \\
3.8 \\
(3)\end{array}$ & $\begin{array}{c}53.5 \pm 7.5 \\
10.6 \\
(2)\end{array}$ & $\begin{array}{c}47.2 \pm 11.2 \\
15.9 \\
(2)\end{array}$ & & $\begin{array}{c}19.3 \pm 9.0 \\
15.6 \\
(3)\end{array}$ & $\begin{array}{c}89.5 \pm 5.5 \\
7.8 \\
(2)\end{array}$ & $\begin{array}{c}72.0 \pm 4.0 \\
5.6 \\
(2)\end{array}$ \\
\hline
\end{tabular}

* All ( $\rho)$ values are expressed in percentages.

$\ddagger$ Transtissue and intratissue extractions are calculated as $[1-$ corresponding $(\rho)] \times 100$.

\$Standard deviation of the mean.

II Standard deviation from the range.

I Transfer constants inside the muscle cells.

${ }^{5} \mathrm{H} /{ }^{14} \mathrm{C}$ ratios in testosterone glucuronide. In six subjects, the ${ }^{8} \mathrm{H} /{ }^{44} \mathrm{C}$ ratios of arterial testosterone glucuronide (TG) were all significantly higher than those observed in the corresponding arterial free testosterone, indicating that testosterone glucuronide is not uniquely derived from blood free testosterone. In three subjects studied, the ${ }^{8} \mathrm{H} /{ }^{44} \mathrm{C}$ ratios of the renal TG was $2,2.5$, and 3 times higher than the corresponding ratios in arterial TG and the ${ }^{8} \mathrm{H} /{ }^{4} \mathrm{C}$ ratios of mesenteric TG, 1.8, 2.0, and 2.1 times higher than the ratios in arterial TG, indicating that testosterone was conjugated in the renal and mesenteric cells. Furthermore, the ${ }^{3} \mathrm{H} /{ }^{14} \mathrm{C}$ ratios of renal

TABLE VI

Tissue Metabolic Clearance Rates* (Liters/Day and \% of Total MCR) and Contribution $\ddagger$ of Each Tissue to the Total Conversion between $T$ and $\Delta \S$

\begin{tabular}{|c|c|c|c|c|c|c|}
\hline \multirow[t]{2}{*}{ Tissue or area } & \multicolumn{2}{|c|}{$\mathrm{MCR}^{\mathrm{T} *}$} & \multicolumn{2}{|c|}{ MCR $\triangle *$} & $\begin{array}{c}\% \text { of totalt } \\
\rho_{\text {T } \Delta} \\
\text { B B }\end{array}$ & $\begin{array}{c}\% \text { of totalt } \\
\rho_{\mathrm{BB}}^{\Delta \mathrm{T}}\end{array}$ \\
\hline & liters/day & $\%$ & liters/day & $\%$ & & \\
\hline Liver & $552 \pm 47(8) \|$ & $40 \pm 7.0$ & $463 \pm 52(7) \rrbracket$ & $29 \pm 4.7$ & $2.7 \pm 1.2(7)$ & $6.7 \pm 2.4(8)$ \\
\hline Mesenteric area & $384 \pm 60(10)$ & $25 \pm 3.8$ & $451 \pm 68(10)$ & $26 \pm 3.2$ & $2.2 \pm 0.5(10)$ & $3.1 \pm 1.4(10)$ \\
\hline Kidneys & $208 \pm 52(6)$ & $16 \pm 4.0$ & $252 \pm 47(7)$ & $16 \pm 2.8$ & $4.8 \pm 0.9(7)$ & $7.6 \pm 3.3(6)$ \\
\hline Posterior limbs & $140 \pm 39(8)$ & $10 \pm 3.0$ & $211 \pm 49(8)$ & $14 \pm 3.3$ & $1.0 \pm 0.2(8)$ & $3.9 \pm 1.3(8)$ \\
\hline Lungs & $* *$ & & $* *$ & & $34.0 \pm 6.1(3)$ & $45.4 \pm 16.4(3)$ \\
\hline
\end{tabular}

* Tissue metabolic clearance rates (liters/day of whole blood calculated as tissue blood flow $\times$ transtissue extraction/100.

$\ddagger \%$ of total $\rho_{\mathrm{BB}}^{\mathrm{T} \Delta}$ or $\Delta \mathrm{T}$ calculated as $\frac{\rho_{\mathrm{AV}}^{\mathrm{T} \Delta} \text { or } \Delta \mathrm{T}}{{ }^{\rho} \mathrm{TB} \text { or } \Delta \mathrm{T}} \times \frac{\text { tissue blood flow }}{\text { cardiac output }} \times 100$.

$\S$ All values are mean \pm SE.

T Values corrected for the extraction across the mesenteric area.

|l Number of dogs in parenthesis.

** Lung metabolic clearance rates were not calculated (see Discussion). 
TG was $25 \%$ higher than the ratios of the free renal testosterone, indicating that in the renal cells TG did not originate uniquely from free $\mathrm{T}$.

\section{DISCUSSION}

In these experiments, it should be pointed out that the transfer constants across or inside each tissue are quite variable in the dogs studied and several important points should be mentioned to explain these apparent discrepancies: (a) Differences in metabolism could exist from dog to dog, apart from the other following factors. (b) In spite of an extensive purification of the plasma steroids, the variations in the blood concentrations of labeled $\mathrm{T}$ and $\Delta$ were $\pm 10 \%$ in some cases. In these instances, the errors in the calculated results could be appreciable. (c) In acute experiments on anesthetized dogs, the blood flow across any tissue can vary (31), and furthermore, anaesthesia can alter certain functions, particularly those of the liver. Theoretically, our catheters should not influence tissue blood flows (19), but this possibility is not definitely excluded. $(d)$ The transpulmonary extraction of $T$ and $\Delta$ were quite variable and for this reason pulmonary $\mathrm{MCR}^{\mathbf{T}}$ and $\mathrm{MCR}^{\Delta}$ were not calculated.

Unlike the human (6-9), the mean values for blood MCR of testosterone and androstenedione are not significantly different in dogs. The MCR of testosterone, however, is higher and the MCR of androstenedione is lower than that found in humans. Furthermore, there is no difference in male and female dogs for both the MCR of testosterone and androstenedione. These species differences and the greater conversion of blood $\mathrm{T}$ to blood $\Delta$ strongly suggest that, unlike the human, there is a much lower binding of testosterone to protein in dogs.

If, as has been done in the human (5), the MCR of testosterone and androstenedione are compared with the mean hepatic blood flow in our dogs (1053 liters/day), at least $30 \%$ of the total testosterone metabolism and $40 \%$ of the total androstenedione metabolism occurs extrahepatically. It is evident from the individual tissue MCR that these values are well underestimated because the hepatic $\mathrm{MCR}^{\mathrm{T}}$ and $\mathrm{MCR}^{\Delta}$ represent only $40 \%$ and $29 \%$ of the total $M R^{x}$ and $M C R^{\Delta}$. It should also be pointed out that the $\mathrm{MCR}^{\mathbf{T}}$ and $\mathrm{MCR}^{\Delta}$ in the mesenteric area are not significantly different from their respective hepatic MCR's. If $\mathrm{T}$ and $\Delta$ were secreted into the bile and reabsorbed by the intestine, our mesenteric metabolic clearance rates would be underestimated.

The blood transfer constants between $\mathrm{T}$ and $\Delta$ are greater in dogs than in humans (5). The greater conversion of blood $\mathrm{T}$ to blood $\Delta$ may be due to a lower testosterone protein binding affinity and may also explain, at least in part, the greater testosterone MCR in dogs. In agreement with the values found for the inter- conversion of estrone and estradiol in humans (28), the over-all interconversion between $\mathrm{T}$ and $\Delta$ in the dog is in favor of the 17-ketone, androstenedione. However, when examined individually, the transtissue transfer constants between $T$ and $\Delta$, while tending to favor the formation of the 17-ketone compound, are not statistically different, with the exception of the lung. Furthermore, the tissue $M C R^{\Delta}$ is not significantly higher than the corresponding tissue $\mathrm{MCR}^{\mathrm{T}}$, except in the posterior limb.

Rivarola et al. (9) have reported that in humans not more than $28 \%$ of the total conversion of blood $\mathrm{T}$ to blood $\Delta$, and not more than $16 \%$ of the total conversion of blood $\Delta$ to blood $\mathrm{T}$ occurs in the splanchnic system. These values, as well as the values obtained by the same authors for the extraction of $\mathrm{T}$ and $\Delta$, are very difficult to interpret because they are calculated from radioactive concentrations obtained from a peripheral vein. These data are not necessarily equal to the radioactive concentrations entering the splanchnic circulation, particularly if, as in dogs, $\mathrm{T}$ and $\Delta$ are extracted and interconverted peripherally and in the mesenteric area. Furthermore, when compared with the total interconversion, the splanchnic interconversion should be corrected by a factor, splanchnic blood flow over total cardiac output. When corrected for their respective blood flow, the liver, mesenteric area, kidneys, and posterior limbs are each responsible for less than $10 \%$ of the blood interconversion between $\mathrm{T}$ and $\Delta$. In other words, more than $90 \%$ of the total interconversion occurs extrahepatically. The lung is by far the most important contributor to the blood interconversion of $T$ and $\Delta$ in the dog, undoubtedly due primarily to its higher blood flow.

In all of the organs or areas studied, the interconversion between $\mathrm{T}$ and $\Delta$ inside the tissue was definitely higher than the corresponding interconversion across the tissue. Furthermore, the intratissue interconversion could be underestimated if the tissue extracts were contaminated by $\mathrm{T}$ and $\Delta$ present in the interstitial water. This means that part of the $\mathrm{T}$ or $\Delta$ formed from its precursor inside the cells is further metabolized and does not appear in the efferent vein. It is possible that this "cellular" compound has an important local metabolic effect before being metabolized, and this action would not be reflected in the plasma or blood concentration.

The canine hepatic extraction of testosterone is higher than in humans $(5,9)$, which is another possible explanation for the high testosterone metabolic clearance rate found in dogs. On the contrary, the hepatic extraction of androstenedione is lower in dogs than in the humans but it is possible that the value found in humans by Rivarola et al. (9) is overestimated for reasons already mentioned. The transhepatic extraction of $T$ was 
not significantly lower than the extraction of $\mathrm{T}$ formed in the liver. Similar values calculated by Horton and Tait (5), in the human, gave $60 \%$ for the maximal extraction of $\mathrm{T}$ across the liver and $98 \%$ for the extraction of $T$ formed in the hepatic cells; however, the calculations used to evaluate the extraction of $T$ formed in the liver could have been overestimated by the extrahepatic production of testosterone glucuronide (see below), by the conversion of $\Delta$ to $\mathrm{T}$ in the mesenteric area, and also by the extrasplanchnic metabolism of testosterone.

In the mesenteric area, the kidney, and the lung, the extraction of $T$ and $\Delta$ formed within the cells was significantly higher than the extraction of $T$ presented to the cells via its afferent blood supply. This could be explained by the possibility that the compound circulating in blood could not reach the cells due to a rapid flow rate or to protein binding, or it could mean that the compound made in the tissue from its precursor is metabolized differently from the preformed compound entering the tissue.

As already observed in humans (6), testosterone glucuronide is not uniquely derived from blood testosterone. Furthermore, testosterone glucuronide is not solely made in the liver but also in the mesenteric area and in the kidney, a finding which is in agreement with in vitro (17) and in vivo studies (35). Inside the liver and the kidney, testosterone glucuronide does not seem to derive uniquely from tissue testosterone.

The important interconversion and extraction both inside and across the mesenteric area emphasizes the importance, at least in dogs, of comparing portal vein blood with hepatic vein blood during the study of the role of the liver in steroid metabolism.

In agreement with other studies $(15,16)$, the canine renal tissue very actively metabolizes testosterone and androstenedione. In one human subject, Rivarola et al. (9) did not find any extraction and interconversion of $\mathrm{T}$ and $\Delta$ by the kidney.

It is impossible to conclude from our study whether some fraction of free and conjugated testosterone or free androstenedione, formed in the kidney, is directly secreted into the urine without equilibration with the corresponding blood compound.

\section{APPENDIX}

1. The subsequent equations show the derivation of formulas used to calculate all tissue transfer constants. These mathematical formulas were derived using the kidney as a model (Fig. 1); this model can be applied to any other tissue.

From Fick's principle and assuming that testosterone is not formed in the renal tissue, the extraction of $T$ across the kidney (KE) will be:

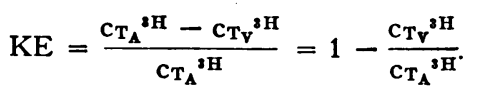

Since the transfer constant from arterial $\mathrm{T}$ to venous $\mathrm{T}$ across the kidney $\left(\begin{array}{c}\mathrm{TT} \\ \rho \mathrm{AV}\end{array}\right)$ is equal to $(1-\mathrm{KE})$, the equation 1 becomes:

$$
\rho_{\mathrm{AV}}^{\mathrm{TT}}=\frac{\mathrm{c}_{\mathrm{T}_{\mathrm{V}}{ }^{3 \mathrm{H}}}}{\mathrm{c}_{\mathrm{T}_{\mathrm{A}}{ }^{3 \mathrm{H}}}} .
$$

However, in this study, the above equation is not entirely correct, since a fraction of $\Delta-^{3} \mathrm{H}$ entering the kidney will leave this tissue as $\mathrm{T}-{ }^{3} \mathrm{H}$, it must therefore be subtracted from $\mathrm{T}_{\mathrm{v}^{-}{ }^{3} \mathrm{H}:}$

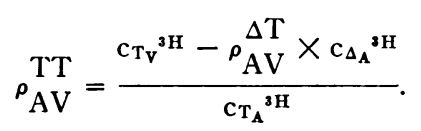

The same relation being true for the other label, ${ }^{14} \mathrm{C}$ :

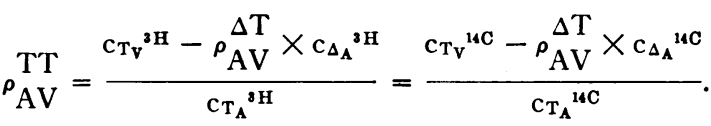

Isolating $\rho_{\mathrm{AV}}^{\Delta \mathrm{T}}$ from equation 4 :

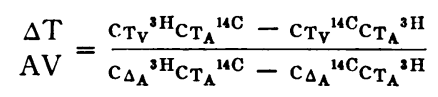

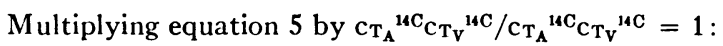

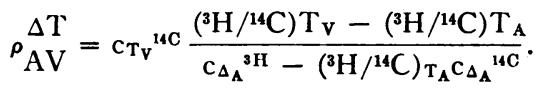

Multiplying equation 6 by $\mathrm{c}_{\Delta_{\mathbf{A}}}{ }{ }^{\mathrm{C}} / \mathrm{c}_{\Delta_{\mathbf{A}}}{ }^{\mathrm{MC}}=1$ :

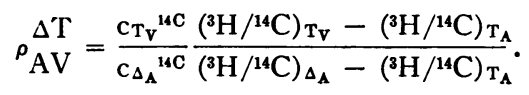

Equation for $\rho_{\mathrm{AV}}^{\mathrm{T} \Delta}$ can be similarly derived:

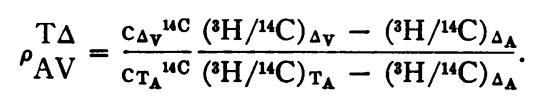

Substituting the $\rho_{\mathrm{AV}}^{\Delta \mathrm{T}}$ value, calculated from equation 7 , in equation $3 \rho_{\mathrm{AV}}^{\mathrm{TT}}$ can now be calculated and similarly the $\rho_{\mathrm{AV}}^{\Delta \Delta}$ is equal to:

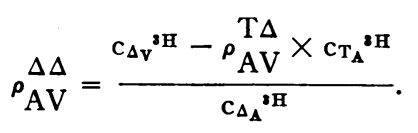

To calculate transfer constants inside the renal cells, we must assume that all arterial $\mathrm{T}$ or $\Delta$ enters the cellular pool and then:

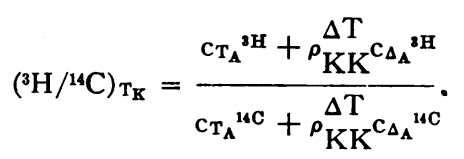

Solving equation 10 for $\rho_{\mathrm{KK}}^{\Delta \mathrm{T}}$ :

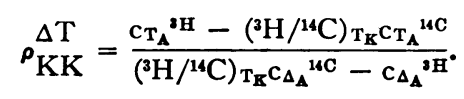


Similarly ${ }^{\mathrm{T} \Delta} \mathrm{KK}$ is equal to:

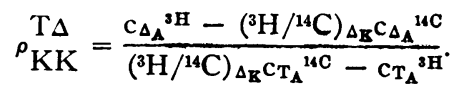

At equilibrium: $\rho_{\mathrm{AV}}^{\Delta \mathrm{T}}=\rho_{\mathrm{AK}}^{\Delta \Delta} \times \rho_{\mathrm{KK}}^{\Delta \mathrm{T}} \times \rho_{\mathrm{KV}}^{\mathrm{TT}}$.

And then:

$$
\rho_{\mathrm{KV}}^{\mathrm{TT}}=\frac{\rho_{\mathrm{AV}}^{\Delta \mathrm{T}}}{\rho_{\mathrm{AK}}^{\Delta \Delta} \times \rho_{\mathrm{KK}}^{\Delta \mathrm{T}}}
$$

Assuming again that $\rho_{\mathrm{AK}}^{\Delta \Delta}$ is equal to 1 , and $\rho_{\mathrm{AV}}^{\Delta \mathrm{T}}$ and $\rho_{\mathrm{KK}}^{\Delta \mathrm{T}}$ being known from equations 7 and $11, \rho_{\mathrm{KV}}^{\mathrm{TT}}$ can be calculated; if some arterial $\Delta$ does not enter the kidney cellular pool $\left(\begin{array}{c}{ }_{\rho} \Delta \\ \mathrm{AK}\end{array} 1\right)$ the $\rho_{\mathrm{KV}}^{\mathrm{TT}}$ value will be underestimated. In a similar manner :

$$
\rho_{\mathrm{KV}}^{\Delta \Delta}=\frac{\rho_{\mathrm{AV}}^{\mathrm{T} \Delta}}{\rho_{\mathrm{AK}}^{\mathrm{TT}} \times \rho_{\mathrm{KK}}^{\mathrm{T} \Delta}} .
$$

2. Blood transfer constants were calculated according to the formulas derived by Gurpide et al. (26) they were:

$$
\begin{aligned}
\mathrm{T}_{\Delta} & =\frac{\left({ }^{3} \mathrm{H} /{ }^{14} \mathrm{C}\right) \text { infused }}{\left({ }^{3} \mathrm{H} /{ }^{14} \mathrm{C}\right)_{\Delta_{\mathrm{A}}}} \\
\rho_{\mathrm{BB}}^{\Delta \mathrm{T}} & =\frac{\left({ }^{3} \mathrm{H} /{ }^{14} \mathrm{C}\right)_{\mathrm{T}_{\boldsymbol{A}}}}{\left({ }^{3} \mathrm{H} /{ }^{14} \mathrm{C}\right) \text { infused }}
\end{aligned}
$$

\section{ACKNOWLEDGMENTS}

The assistance given by Dr. Serge Carriere of Maisonneuve Hospital for the surgical preparation of the dogs is gratefully acknowledged. The author is also indebted to Dr. Erlio Gurpide of Columbia University for his assistance with the mathematical portion of this paper. Thanks are also due to Miss Lise Heroux for technical assistance and to Miss Micheline Caron for secretarial assistance.

This work was supported by Grant MA-1859 from the Medical Research Council of Canada.

\section{REFERENCES}

1. Vande Wiele, R. L., P. C. MacDonald, E. Gurpide, and S. Lieberman. 1963. Studies on the secretion and interconversion of the androgens. Recent Progr. Hormone Res. 19: 275.

2. Horton, R., J. Shinsako, and P. H. Forsham. 1965. Testosterone production and metabolic clearance rates with volumes of distribution in normal adult men and women. Acta Endocrinol. 48: 446.

3. Tait, J. F., and S. Burstein. 1964. In vivo studies of steroid dynamics in man. In The Hormones. G. Pincus, K. Thimann, and E. B. Astwood, editors. Academic Press Inc., New York. 5: 441.

4. Tait, J. F., and R. Horton. 1964. Some theoretical considerations on the significance of the discrepancy in uri- nary and blood production rate estimates of steroid hormones. Steroids. 14: 365.

5. Horton, R., and J. F. Tait. 1966. Androstenedione production and interconversion rates measured in peripheral blood and studies on the possible site of its conversion to testosterone. J. Clin. Invest. 45: 301.

6. Korenman, S. G., and M. B. Lipsett. 1964. Is testosterone glucuronoside uniquely derived from plasma testosterone? J. Clin. Invest. 43: 2125.

7. Southren, A. L., G. G. Gordon, S. Tochimoto, G. Pinzon, D. R. Lane, and W. Stypulkowski. 1967. Mean plasma concentration, metabolic clearance and basal plasma production rates of testosterone in normal young men and women using a constant infusion procedure: effect of time of day and plasma concentration on the metabolic clearance rate of testosterone. J. Clin. Endocrinol. Metab. 27: 686.

8. Bardin, C. W., and M. B. Lipsett. 1967. Testosterone and androstenedione blood production rates in normal women and women with idiopathic hirsutism or polycystic ovaries. J. Clin. Invest. 46: 891.

9. Rivarola, M. A., R. T. Singleton, and C. J. Migeon. 1967. Splanchnic extraction and interconversion of testosterone and androstenedione in man. J. Clin. Invest. 46: 2095.

10. Horton, R., and J. F. Tait. 1967. In vivo conversion of dehydroisoandrosterone to plasma androstenedione and testosterone in man. J. Clin. Endocrinol. Metab. 27: 79.

11. Thomas, P. Z., and R. I. Dorfman. 1964. Metabolism in vitro of androst-4-ene-3,17-dione-4- ${ }^{14} \mathrm{C}$ by rabbit skeletal muscle strips. J. Biol. Chem. 239: 762.

12. Wotiz, H. H., H. Mescon, H. Doppel, and H. M. Lemon. 1956. The in vitro metabolism of testosterone by human skin. J. Invest. Dermatol. 26: 113.

13. Rongone, E. L. 1966. Testosterone metabolism by human male mammary skin. Steroids. 7: 489.

14. Acevedo, H. F., and J. W. Goldzieher. 1964. The metabolism of $4-^{14} \mathrm{C}$-4-androstene-3,17-dione by normal human prostatic tissue. Biochim. Biophys. Acta. 82: 118.

15. West, C. D., and L. T. Samuels. 1951. The metabolism of testosterone and related steroids by kidney tissue. J. Biol. Chem. 190: 827.

16. Kochakian, C. D., V. S. Raut, and G. Kinson. 1961. Use of coenzymes I and II in interconversion of testosterone and androstenedione. Amer. J. Physiol. 200: 348.

17. Kreek, M. J., F. G. Guggenheim, J. E. Ross, and D. F. Tapley. 1963. Glucuronide formation in the transport of testosterone and androstenedione by rat intestine. Biochim. Biophys. Acta. 74: 418.

18. Levin, J., E. H. Friedrich, and J. Lobotsky. 1965. Steroid adsorption with polyethylene tubing. J. Clin. Endocrinol. Metab. 25 : 1519.

19. Herd, J. A., and A. C. Barger. 1964. Simplified technique for chronic catheterization of blood vessels. J. Appl. Physiol. 19: 791.

20. Blaquier, J., E. Forchielli, and R. I. Dorfman. 1967. In vitro metabolism of androgens in whole human blood. Acta Endocrinol. 55: 697.

21. Nowaczynski, W., and J. Genest. 1955. Recovery of aldosterone, hydrocortisone and cortisone following dialysis. J. Clin. Endocrinol. Metab. 15: 1310.

22. Simpson, S. A. von, J. F. Tait, A. Wettstein, R. Neher, J. von Euw, O. Schindler, and T. Reichstein. 1954. Die konstitution des aldosterons über bestandteile dernebennieren rinde und verwandte stoffe. Helv. Chim. Acta. 37: 1200. 
23. Poos, G. I., G. E. Arth, R. E. Beyler, and C. H. Sarett. 1953. Approaches to the total synthesis of adrenal steroids. V. $4 \beta$-Methyl-7-ethylene-dioxy-1,2,3,4,4A $\alpha, 4 b, 5,6,7,8$, $10,10 \alpha$ - $\beta$-dodecahydrophenanthrene- $4 \beta$-ol-1-one and related tricyclic derivatives. J. Amer. Chem. Soc. 75: 422.

24. Sandor, T., and A. Lanthier. 1960. Biosynthesis of two steroid glycols from $17 \alpha$-hydroxyprogesterone by surviving human ovarian slices. Can. J. Biochem. Physiol. 38: 1167.

25. Tait, J. F. 1963. Review: the use of isotopic steroids for the measurement of production rates in vivo. J. Clin. Endocrinol. Metab. 23: 1285.

26. Gurpide, E., J. Mann, and S. Lieberman. 1963. Analysis of open systems of multiple pools by administration of tracers at a constant rate or as a single dose as illustrated by problems involving steroid hormones. J. Clin. Endocrinol. Metab. 23: 1155.

27. Green, H. D., L. S. Hall, J. Sexton, and C. P. Deal. 1959. Autonomic vasomotor responses in the canine hepatic arterial and venous beds. Amer. J. Physiol. 196: 196.

28. Longcope, C., D. S. Layne, and J. F. Tait. 1968. Metabolic clearance rates and interconversions of estrone and $17 \beta$-estradiol in normal males and females. $J$. Clin. Invest. $47: 93$.
29. Grim, E. 1963. The flow of blood in the mesenteric vessels in circulation. In Handbook of Physiology. W. F. Hamilton and P. Dow, editors. The American Physiological Society, Washington, D. C. 2: 1439.

30. Hollenberg, M., and J. Dougherty. 1966. Liver blood flow measured by portal venous and hepatic arterial routes

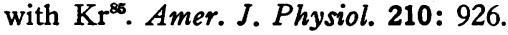

31. Birth, A. G., B. H. Casey, and R. M. Zakheim. 1967. Hepatic blood flow measured by the Krypton- 85 clearance technique. Surgery. 62: 174.

32. Blalock, A., and M. F. Mason. 1936. Observations on the blood flow and gaseous metabolism of the liver of unanesthetized dogs. Amer. J. Physiol. 117: 328.

33. Stewart, J. D., J. G. Stephens, M. B. Leslie, B. A. Portin, and W. G. Schenkje. 1958. Portal hemodynamics under varying experimental conditions. Ann. Surg. 147: 868.

34. Selkurt, E. E. 1963. The renal circulations in Circulation. In Handbook of Physiology. W. F. Hamilton and P. Dow, editors. The American Physiological Society, Washington, D. C. 2: 1457.

35. Cohn, G. L., M. Hume, and P. K. Bondy. 1960. The in vivo glucuronide conjugation of 17 -ketosteroids by dog kidney. Acta Endocrinol. Suppl. 51: 729. 